\title{
A.H. Snyman
}

\section{CORINTHIANS 1:18-31 FROM A RHETORICAL PERSPECTIVE}

\begin{abstract}
The approach followed in this article differs from that of researchers who force ancient rhetorical categories on a text or who regard only a few stylistic devices as rhetorical. The analysis is done in terms of what is called a "grounded theoretical approach." This approach is briefly summarised, followed by a description of the rhetorical status of the letter and a systematic analysis of 1 Corinthians 1:18-31. It is argued that these fourteen verses form an integral part of Paul's rhetorical strategy (constructed from the text itself) and aimed at persuading the Corinthians to accept his explanation of the gospel. The article concludes that a text-centered approach, with its focus on the functional aspects of the text, provides a better alternative to existing approaches, that focus on the formal aspects of the text.
\end{abstract}

\section{INTRODUCTION}

Rhetoric in Paul's letters has been studied in terms of two approaches. The first was to apply an external model in order to describe a letter's rhetorical structure. Many letters have been analysed in this way, using the Graeco-Roman rhetorical system with its well-known exordium, propositio, narratio, probatio and conclusio. Examples are the analyses of Galatians by Betz (1979) and of 1 Corinthians by Mitchell (1991) and Witherington (1995).

According to the second approach, rhetoric has been restricted to a few rhetorical techniques (such as rhetorical questions) and to some stylistic devices (such as chiasms, parallelisms and alliteration). Remarks on these are usually found in commentaries on Paul's letters, including those of Fee (1988) and Thiselton (2000), which could be regarded as standard commentaries on 1 Corinthians. These remarks are sporadic and the functions of the devices are not always described.

By contrast to these two approaches, rhetoric in this article is understood as a description of all the means in the text (way of argumentation, type of arguments used, supportive rhetorical techniques, etc.) which the author uses in order to persuade his readers to accept his point of view. An external model is not forced upon the text and everything that contributes to the process of persuasion is identified and its function described within the context. A recent 
proposal for such a text-centered rhetorical analysis is Tolmie's Persuading the Galatians (2005). The proposal includes the following, which is not to be regarded as a fixed methodology, but rather as a general guideline (Tolmie 2005:28-29):

- A description of the rhetorical status or context of the letter, that is, what Paul wants to achieve in the letter as a whole.

- A descriptive analysis of how he tries to persuade his readers, based on a so-called "minimal theoretical framework" that consists of the following aspects: the identification of the dominant rhetorical strategy in each section by describing its primary rhetorical objective and determining how he attempts to achieve it. In this process the focus is on the type of arguments used and on the way he argues to persuade his audience. Finally, the so-called rhetorical techniques, which serve to enhance the impact of his communication, are identified and their function described.

The purpose of this article is to apply Tolmie's alternative approach to 1 Corinthians 1:18-31 and to determine its value by describing the process of persuasion in these fourteen verses.

\section{RHETORICAL CONTEXT}

The rhetorical situation or context in which Paul wrote this letter might be conceived as follows: "Those of Chloe" in 1:11 supplied him with oral information about the situation in Corinth. They most probably also presented him with the letter referred to in 7:1 (Schüssler-Fiorenza 1987:395). From these two sources Paul has learned, first, about the divisions and partisanships in Corinth, which had implications for his apostolic authority. It is unlikely that a group of antiPauline agitators were causing these problems, as Marshall (1987:23-27) argues. The problems were essentially internal and resulted in divisions among the Corinthians themselves (Schüssler-Fiorenza 1987:397-398; Pogoloff 1992: 237ff. and Witherington 1995:74). Fee (1988:6) also agrees that the church was experiencing internal strife, but argues convincingly that the greater problem was division between Paul as the founder of the church and some influential teachers, who were leading the Corinthians in an anti-Pauline direction. For Paul this greater conflict presented a crisis over his apostolic authority, as well as the truth of his message. Exegetes agree that the key issue between Paul and his audience was what it meant to be pneumatikos. The Corinthians made glossolalia the basic criterion of spirituality, while their interest in sophia and gnosis gave them special wisdom and superior knowledge. All of this was opposed to both Paul and his gospel and resulted in boasting and false confidence, which needed to be addressed. 
Secondly, 1 Corinthians was written in response to certain practical issues raised in the letter he received from them. The major issues which needed to be settled were marriage and sexuality (5-7), meat sacrificed to idols (8:1-11:1), worship (11:2-14:40), resurrection (15:12-37), and the collection for the saints $(16: 1-4)$. In response to these issues, as well as to the oral reports of Chloe's people, Paul addressed various - mainly behavioural - concerns in the letter.

In her much-quoted article "Rhetorical situation and historical reconstruction in 1 Corinthians," Schüssler-Fiorenza (1987:397-398) describes the rhetorical situation as follows: The Corinthians debated as to how their new life in Christ could be realised in the midst of a society rooted in divisions between Greeks and Jews, slave and free, men and women, etc. These debates dealt with issues such as "no longer male and female" and marriage relationships. In the light of competing interpretations and practices they decided to write to different missionaries (including Paul) for their advice, since some of the interpretations most likely originated in different theological views held by these missionaries. This consultation process did not mean that they would accept such advice without judgment in terms of their own pneumatic self-understanding. According to some of the Corinthians, Paul was not well qualified in terms of pneumatic competence. The apostle must somehow have learned this and in order to convince them to accept his interpretation, he had to argue why they should follow his instructions and not those of the others. In the process of persuasion, Paul presented himself as the sole founder and father of the church in Corinth who had to be obeyed, and not as one apostle among others.

Whether one accepts this specific reconstruction or not, the broad picture remains the same: The letter is dominated by Paul's attempt to persuade the Corinthians to accept his authority as apostle (including the truth of the gospel he preaches) and to follow his instructions in realising their new life in Christ. $\mathrm{He}$ is not addressing a single subject, but a wide variety of issues, using a variety of arguments and persuasive techniques. The aim of this article is to examine these in the fourteen verses of 1:18-31.

\section{ANALYSIS OF 1 CORINTHIANS 1:18-31}

\subsection{Introduction}

Two issues are important before commencing with the analysis:

First, it should be noted that scholars who prefer to use the Graeco-Roman rhetorical system to analyse Paul's letters define 1:18-31 as part of the letter's probatio. However, they differ considerably as to its demarcation. Witherington (1995:44) defines 1:18-16:12 as the probatio and divides it into nine arguments. 


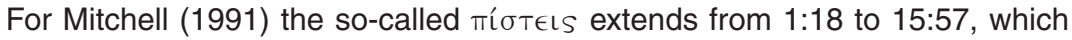
is divided into four proofs. She regards $15: 58$ as the $\epsilon \pi$ í $\lambda o \gamma o s$ or conclusion, while 16:1-24 forms the epistolary closure. According to Schrage (1991:167), $1: 18-25$ is the argumentatio or proof of the narratio in 1:11-17, which explains the propositio in 1:10. Bünker (1984:109-111) regards 1:18-2:16 as the letter's narratio. This wide variety of interpretations, using the same rhetorical system, throws into serious doubt the theoretical justification for employing categories of classical rhetoric with regard to Paul's letters. For this reason I prefer - in line with Tolmie and others - a text-centered approach, where the text itself serves as a starting-point of the analysis.

Secondly, in this article, 1 Corinthians 1:18-31 is demarcated as a separate section based on rhetorical considerations from the text itself. In 1:10-17 Paul appeals to the Corinthians to be united, but in 1:18 he changes his rhetorical strategy from an appeal to an explanation. Verse 17 functions as a transition from one verse to the other, since it concludes the discussion on the reasons for their internal differences and introduces the extensive explanation on the meaning of the gospel. The explanation extends from 1:18 to 2:16. In 3:1 Paul returns to the divisions among the Corinthians, discussing them from a new perspective and elaborating on his relationship with Apollos. 1 Corinthians 1:18-2:16 could thus be regarded as a separate phase for analysis.

1 Corinthians 1:18-2:16 may be divided into four sections, with the same dominant rhetorical strategy, namely an explanation of the gospel. The four sections indicate four aspects of the gospel and are also demarcated by rhetorical considerations. Verses $18-25$ are separated from verses $26-31$ because of the use of the verb $\beta \lambda \epsilon \in \epsilon \in \epsilon$ in 1:26, the change to the second person plural in 1:26-31 and the vocative $\dot{\alpha} \delta \in \lambda \phi o$, frequently used by Paul to introduce a new

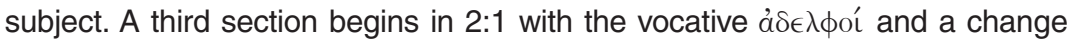
from the second person plural to the first person singular. The fourth section (2:6-16) is also demarcated by a change in person (from the first person singular to the first person plural) and deals with a new theme explaining yet another aspect of the gospel. Thus, the four sections of the phase 1:18-2:16 are $1: 18-25 ; 1: 26-31 ; 2: 1-5$ and $2: 6-16$.

A dominant feature of this phase is Paul's use of the rhetorical technique of contrast which also characterises other parts of the letter. It is, however, prominent in 1:18-2:16. It is used (implicitly) in 1:17b: "... not in wisdom of word, that the cross of Christ may not be emptied" and is elaborated upon in 1:18-2:16 as a contrast between the wisdom of God versus that of man. As such it is used as the main argumentative technique in 1:18-2:16.

How should one then describe the rhetorical strategy in the phase with its four sections? In the light of the considerations mentioned above, the dominant strategy could be formulated as: "Explaining the gospel by contrasting divine 
and human wisdom." The four aspects related to the gospel are the cross of Christ, the receivers of the gospel, Paul's preaching of the gospel and the work of the Holy Spirit in God's revelation. Only the first two will be addressed in this article and are described as:

- using the contrast to explain the cross of Christ (1:18-25), and

- using the contrast to explain the calling of the Corinthians (1:26-31).

\subsection{Analysis}

\subsubsection{Corinthians 1:18-25: Using the contrast to explain the cross of Christ}

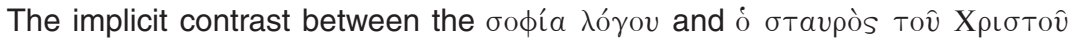
that explains the gospel in 1:17b is made explicit when Paul continues in 1:18:

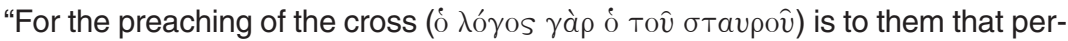

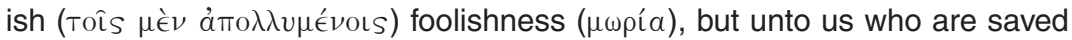

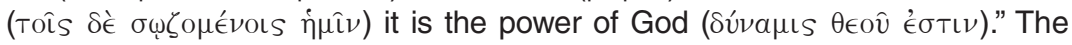

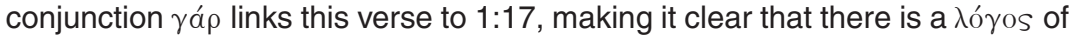

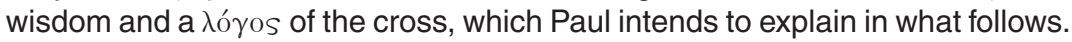
At the same time he introduces the important notion of salvation (Tôิs $\sigma \omega$ -

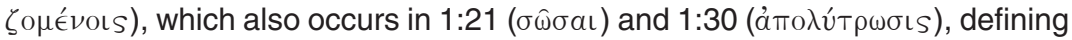
the essence of the gospel. People are saved when "the word of the cross" is accepted in faith.

The verse is characterised by two contrasts, which are rhetorically significant. The first is between "those who perish" and "we who are saved," clearly marked by the particles $\mu \epsilon \in v$ and $\delta \epsilon$. It is an absolute contrast, in which Paul identifies himself with his audience by way of the personal pronoun $\dot{\eta} \mu \hat{\imath} \nu$. The identification is used to associate himself with the Corinthians, rather than

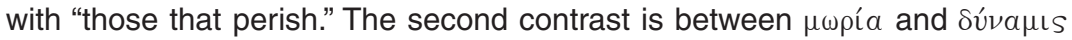

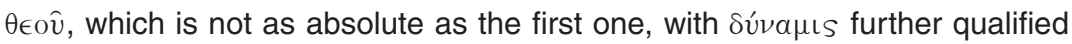
by the genitive $\theta \in o \hat{v}$. Conzelmann (1975:41) remarks that $\theta \in o \hat{v}$ in this instance does not designate the nature of God, but is used as a predicate of "the word of the cross = the gospel." Important for our purpose is the fact that $\mu \omega$ pí $^{\prime}$ and

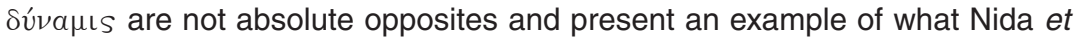
al. (1983:183) call "a shift in expectancy". This shift from the expected to the unexpected is forceful and forms the basis of many well-known rhetorical techniques, usually employed to draw the audience's attention.

In support of what he just said, Paul uses a quotation from Isaiah 29:14:

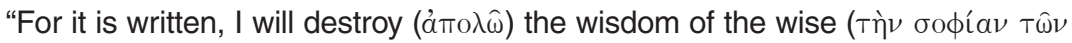




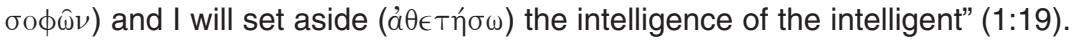
It is evident that this wisdom is a wisdom of this world (verse 20), a wisdom that leaves God out of account and is man-centered. With the word ooфía the quotation makes the point that Paul wants to stress in this instance. In its original context Israel is warned not to try to match wits with God. He will not allow them to do so. In the cross, so Paul argues, God has proved this in an extreme manner (Fee 1988:70).

The quotation emhasises that the destruction of the wise and intelligent is God's work, as is clear by the placement of the two verbs $\dot{\alpha} \pi 0 \lambda \hat{\omega}$ and $\dot{\theta} \theta \in T \eta \dot{\sigma} \sigma \omega$ at the beginning and end of the quotation, respectively. The rhetorical function of such quotations is also important for our purpose. Tolmie (2005:97, 165-176 and 194-195) calls these arguments based on the authority of Scripture. By basing his argument on the scriptural tradition accepted by the majority of his audience as authorative, Paul is able to convince the Corinthians of the saving power of God. He uses this type of argument again to good effect in 1:31.

In verse 1:20 he continues his explanation by way of four rhetorical ques-

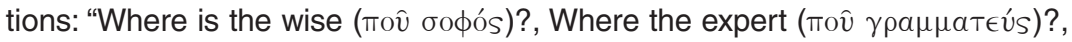

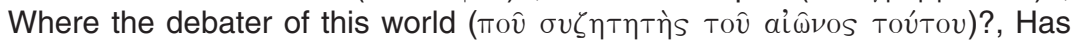

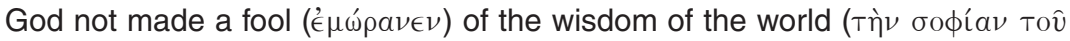

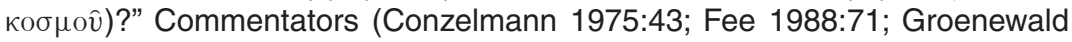

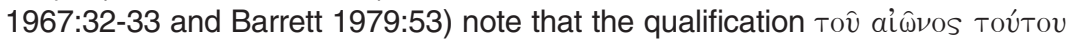
in the third question also applies to the previous two, while it is equivalent in

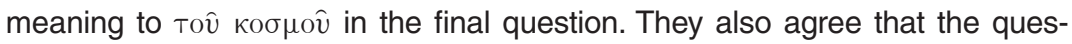
tions reflect the various wise people of the time: the oodoi refers to the Greek

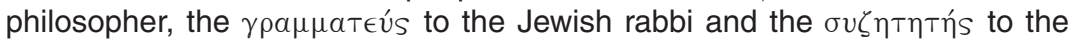
debater among the Corinthians themselves, or in a general sense to both the Greek philosopher and the Jewish rabbi.

The following issues are important from a rhetorical perspective. First, the function of these questions in the context of 1:18-25. Commentators differ on this issue. Groenewald (1967:32) and Fee (1988:70), for example, are of the opinion that they continue the quotation in 1:19 and are used in a sarcastic way: "In view of what God has done in the cross, who is left of the wise of this present age? Where now are all the teachers of wisdom ....?" (Fee 1988:70). Barrett (1979:53) and Thiselton (2000:162) also agree that they serve to drive home the point made in verse 19, rather than to cover new ground. Grosheide (1957:23) comments that they are typical rhetorical questions that do not expect any answers, but have the force of exclamations. Conzelmann (1975:43) only draws attention to the length of the third question and remarks that it provides a climax to the first three. In my opinion, the questions drive home the point made in 1:19 more forcefully than a mere statement of fact would do. This applies especially to the first three - very brief — questions, which 
enable Paul to convey his emotions most emphatically: God has now acted and exposed what the world considers wisdom as the foolishness that it really is. With the fourth question Paul starts his own argument by appealing to what God has done in Christ. In the cross, so he argues, God has made foolish the wisdom of this world. The form of the question in the original expects a positive answer and by being the longest of the four questions placed in a final position, I would consider this one to be climactic, rather than the third question.

Finally, the fourth question provides an argument based on divine initiative. Before Paul sets out to explain the meaning of the cross in detail, he forcefully states the basic argument he is about to use in convincing the Corinthians. They must understand that God himself used the cross to make foolish the wisdom of this world. Because God took the initiative, the Corinthians should be convinced of the authenticity of the whole process.

God revealed the world's wisdom as folly by doing what it had failed to do, namely to save people. This point is made very clear in 1:21: "For since

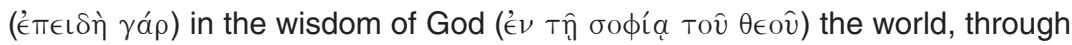

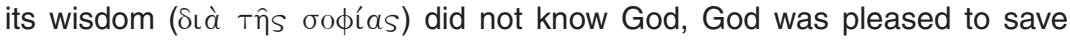

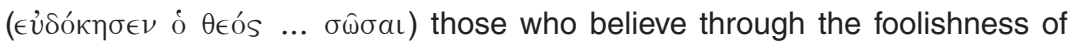

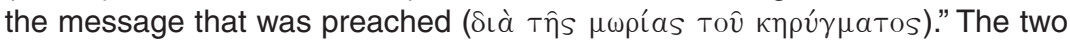

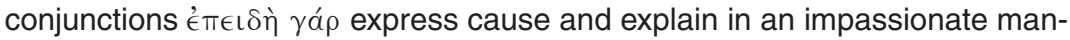

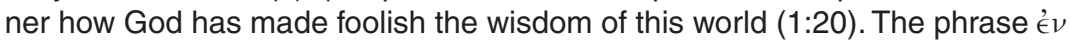

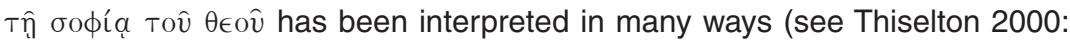
167-169 for a discussion). Barrett (1979:53) gives the best interpretation within the immediate context. According to him, it refers to the scheme or plan prepared and enacted by God himself to save those who believe. It is not a plan that man would have thought of, because it operates through preaching, with its focus on the cross (1:18). This, however, is the way God works - his wisdom versus that of man. The latter is most probably to be understood as Gnosticism, or something akin to Gnosticism.

The direct contrast between the two prepositional phrases $\delta \grave{\iota}$ Tîs $\sigma o \phi i ́ a s$ and

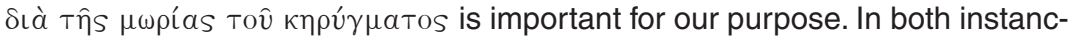
es the preposition $\delta$ iá indicates what people rely on, their way to salvation. Believers accept the preaching of the "word of the cross" in faith and respond positively to God's wisdom, but non-believers reject this wisdom and call it foolishness. The result is that the former are saved and the latter lost. The function of this antithetic presentation is to focus the attention of the Corinthians on the second part of the contrast, namely on God and his way to salvation. As such it provides another example of an argument based on divine initiative.

The next three verses reinforce the contrast between the wisdom of man and that of God (= the cross): "For the Jews request signs and the Greeks

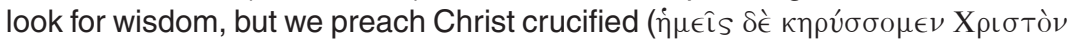




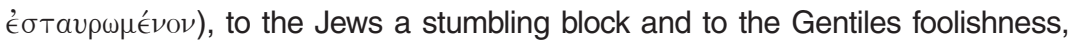

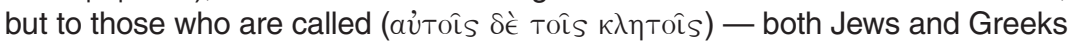

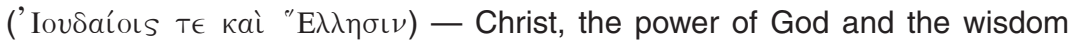

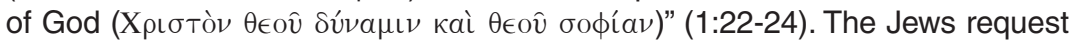
signs as proof of God's saving power, the Greeks seek wisdom as a way to salvation. These two groups (the seekers of power and the seekers of wisdom) are closely linked by $\tau \epsilon$ kai and present the two "basic idolatries of our fallen world," as Fee (1988:75) puts it. By contrast, "we preach Christ crucified ..."

The use of contrast in explaining the "word of the cross" reaches its full force in these three verses. As a mode of persuasion, antithetic presentation - indicated by $\delta \delta^{\prime}$ at the beginning of both verses 23 and $24-$ emphasises the second part of the contrast (Tolmie 2005:61, 159). We may thus speak of a double emphasis or focus of attention in 22-24: first the fact that "we preach Christ crucified" and, secondly, that Christ is "the power and wisdom of God". Read together this means that Christ crucified is where God was pleased to enact his power and wisdom to save mankind. And this is the essence of the "word of the cross" that "we are called to proclaim" (1:23). It is the first time in the letter that a verb in the first person plural is used, its function being to associate Paul with his colleagues versus the Jews and the Greeks.

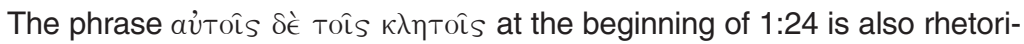
cally significant. It most probably refers to the believers in verse 21 and redefines them in terms of their calling. The one who calls them is God. This is another example of an argument based on divine initiative, used to remind and convince the Corinthians that the acceptance of the "word of the cross" - whether by Jews or by Greeks - is ultimately a divine, not a human, decision.

Verse 25 concludes the argument in 1:18-24: "For the foolishness of God (Tò

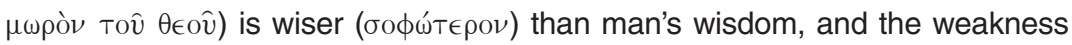

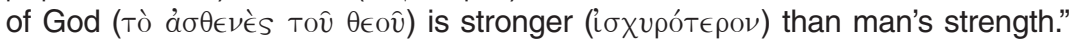
God's foolishness (that is, what He has done in Christ crucified) is in direct contrast with and much wiser than man's wisdom. God's weakness (as illustrated by Christ crucified) is stronger than man's strength. Why? Because it achieved what human wisdom and power failed to achieve: it delivered man from eternal destruction. This is the "word of the cross" that Paul was called to proclaim.

Various rhetorical techniques are used to enhance Paul's communication in this section:

- Repetition of words and phrases throughout the section: Tov at the begin-

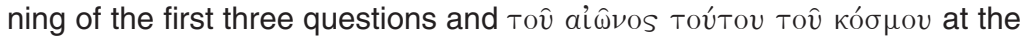

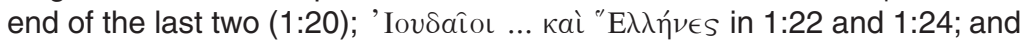
$\theta \in o \hat{v}$ in 1:24. Repetition is an effective rhetorical technique to highlight key notions in a discourse. 
- The use of three brief questions in 1:20 is a forceful way of driving home a point.

- The placement of $\epsilon \dot{v \delta o ́ \kappa \eta \sigma \epsilon \nu}$ at the beginning of the second part of 1:21 is an important notion in understanding Paul's whole argument in 1:21-25 (Kistemaker 1993:58).

- The repetition of the same structure in successive clauses, but with different meanings (as in 1:22 and 1:25) is technically called parison (Nida et al. 1983:180). As a form of repetition it is effective, especially when it is used to emphasise contrasting key concepts, as in 1:25.

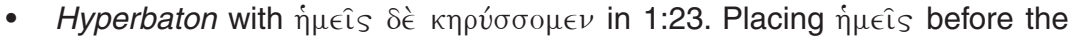
verb highlights the contrast between Paul and his colleagues versus the Jews and the Greeks.

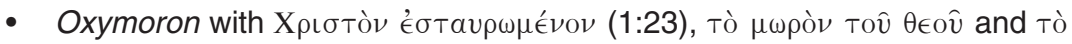

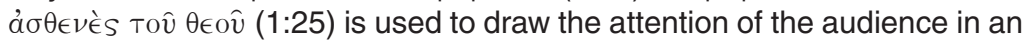
effective manner.

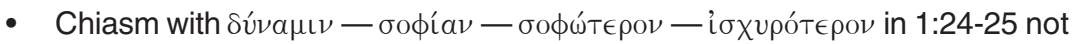
only highlights key concepts in the argument, but also serves to link verses 24 and 25 effectively.

To summarise: Paul's rhetorical strategy in 1:18-25 could be described as "Using the contrast between divine and human wisdom to explain the cross of Christ". The second contrast in 1:18 is strengthened by a shift in expectancy, while Paul identifies himself with his audience by way of inclusive ("we") language. The quotation in 1:19 is an argument based on the authority of Scripture and is used to convince the Corinthians of the saving power of God.

By using four rhetorical questions in 1:20 Paul drives home the point made in $1: 19$ and paves the way for the remainder of his argument in 1:21-25. The fourth question is climactic, picking up the main point in the quotation with an argument based on divine initiative in 1:21. The argument is used to convince the Corinthians of the authenticity of the salvation process. The function of the contrastive $\delta$ tá phrases is to focus on God and his way of salvation, thereby offering another example of an argument based on divine initiative.

In 1:22-24 the use of contrast in explaining the cross reaches its full potential, with the emphasis on the second part of the contrast, expressing the real meaning of the crucifixion. By using the first person plural at the beginning of 1:23 Paul associates himself with his colleagues, while the phrase aưToîs $\delta \dot{e}$

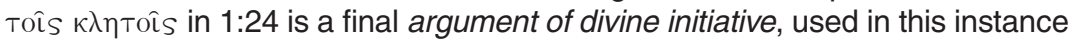
to convince the Corinthians that their salvation was a divine, not a human, decision. Verse 25 concludes the section by contrasting divine and human 
wisdom/strength, arguing that the former is superior to the latter because it achieved what man could not.

Rhetorical techniques that enhance the impact of Paul's communication in 1:18-25 include the repetition of words and phrases, the use of brief sentences, parison, oxymoron, hyperbaton and chiasm.

\subsubsection{Corinthians 1:26-31: Using the contrast to explain the calling of the Corinthians}

To further explain the gospel he preaches, Paul turns from its content to the existence of the believers in Corinth when he writes: "For think ( $\beta \lambda \epsilon ́ \pi \epsilon T \in \gamma \alpha \dot{\alpha} \rho$ )

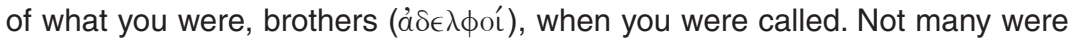

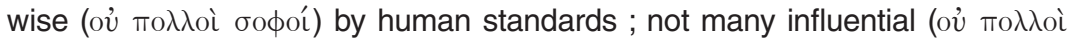

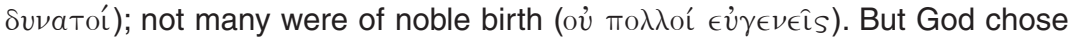

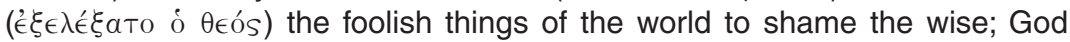

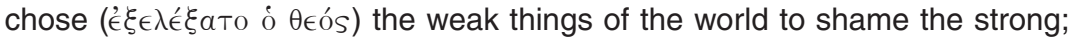

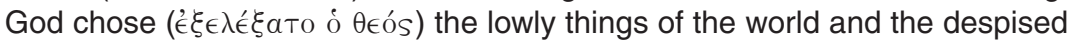
things - the things that are not - to nullify the things that are ( $\tau \grave{a}$ ŏ $v T \alpha$ ), so that no one may boast before him" (1:26-29). The conjunction $\gamma$ á $\rho$ indicates that what follows further explains the gospel. Commentators disagree as to whether $\beta \lambda \epsilon ́ \pi \epsilon \tau \epsilon$ is an indicative or an imperative (see Barrett 1979:56), but the majority of them, as well as all translations, prefer the imperative. With the verb $\dot{\epsilon}^{\prime} \xi \in \lambda \epsilon^{\prime} \xi a \tau$ Toul picks up the notion of "calling" in 1:24 and explains it once again in terms of the wisdom of God versus the wisdom of man: The standards of God in calling the Corinthians differ fundamentally from those accepted by man. Not only is this the case, but God has also overthrown their false standards for two reasons: to shame the wise and influential people of this world (= those outside the church) and to remove any grounds for boasting among the Corinthian believers (= those inside the church) (Barrett 1979:58-59). The latter is one of the main aims of the letter, as is clear from its rhetorical situation.

Paul's rhetorical argument in these four verses is acknowledged by commentators in a sporadic way, focussing mainly on the use of repetition and parallelism in 1:26-28 (Conzelmann 1975:49; Fee 1988:79-83; Thiselton 2000: 183-188). In addition to these techniques, the following four issues are of rhetorical significance. First, the command ( $\beta \lambda \epsilon ́ \pi \epsilon T \epsilon)$ in 1:26, further strengthened by the affectionate $\dot{\alpha} \delta \in \lambda \phi o$, creates the framework for the explanation in $1: 26 \mathrm{~b}-28$ with its various persuasive techniques. Paul expects his audience to pay attention to what he is asking in order to gain a better understanding of the gospel. Secondly, the Corinthians are commanded to contemplate who they were at the time of their calling. This is an argument based on their own 
experience. Such arguments are powerful and effective, since people usually do not doubt their own experiences (Tolmie 2005:101). This is probably what Paul wants to achieve in this instance: he bases his argument on the Corinthians' earlier experiences, which they now cannot deny. He uses their status at the time of their calling to show how different God's perspective is from that of man, thereby further strengthening this important aspect of his argument.

A third issue of rhetorical significance is the three repetitions of $\dot{\epsilon}^{\prime} \xi \in \lambda \epsilon^{\prime} \xi \alpha T 0$ $\dot{o} \theta \in$ ós, which dominates the second part of the contrast (1:27-28). This is yet another example of an argument based on divine initiative - the most explicit of them all. It is used to denote the activity whereby God has called from the midst of the world ( $(\dot{K} \kappa)$ the unworthy of this world to be his people in Corinth. The focus is on the sovereignty of God, who elects whom he wants to (Fee 1988:82). The Corinthians should understand that God is the sole author of their salvation and in calling them, He showed no regard for the wisdom of this world. In this way $\mathrm{He}$ again demonstrated his divine wisdom versus that of man.

The fourth issue that deserves attention is the way in which the contrast in 1:26-28 is structured. God chose the foolish things of this world to shame the wise; He chose the weak things to shame the strong, and he chose the lowly and despised things - and the things that are not - to nullify (not the $\in \dot{v} \gamma \in v \in \hat{i} S$ of 1:26), but Tà övTa. This is another example of a shift in expectancy and is rhetorically significant in that it serves to draw the audience's attention to this final part of the triad, which concludes in 1:29 with the important purpose clause "so that no one may boast before him". With these sets of contrasts, culminating in the last one, Paul displays the complete vindication of God's wisdom over this world and everything "that is" (Thiselton 2000:190).

In the last contrast of the section Paul contrasts the Corinthians emphatically with the $T \grave{a}$ ö $\nu \tau a$ of verse 28 , thereby expressing positively what God has done in calling them: "But because of him ('ُ $\xi$ a Jesus, who has become for us ( $\dot{\eta} \mu \hat{\imath} \nu$ ) wisdom from God, righteousness, holi-

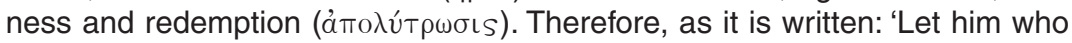
boasts boast in the Lord"' (1:30-31). As in the previous three verses, all the emphasis is on God's activity and on what he has done "in Christ." This argument of divine initiative is followed by two other issues which are important for our purpose: the illogical sequence of the metaphors used for Christ, and the quotation from Scripture.

As far as the sequence of the metaphors is concerned, it is not logical in terms of the saving process. They could be rearranged in exactly the reverse order, namely redemption, righteousness and holiness. Why then this sequence?

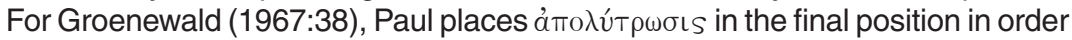
to emphasise the most important thing that God has done for us in Christ. That single word summarises all the promises of the "word of the cross." According 
to Fee (1988:86), they are in this order because each of them is taken from a different sphere and highlights a different aspect of the same event or reality, namely our salvation effected in Christ. Given the trend of Paul's explanation in the previous section, I agree with Groenewald's interpretation: The notion of redemption is central to Paul's understanding of the "word of the cross," because it distinguishes God's wisdom most clearly from that of the world. The notion oc-

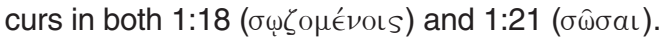

Paul concludes with a quotation from Jeremiah 9:24, but adapts it (as usual) to the present context. As participants of such wealth in Christ the Corinthians, who do not have any self-esteem, could boast only in the Lord. The quotation is used to affirm this truth and provides another example of an argument based on the authority of Scripture. The fact that Paul uses a holy text as part of his argumentation would have reinforced his status in the eyes of those who hear his letter, thereby enhancing the success of his rhetoric.

The following rhetorical techniques strengthen Paul's communication in 1 : 25-31:

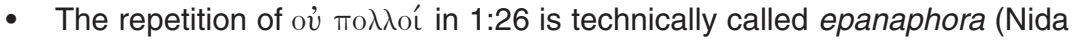
et al. 1983:175). It has a forceful effect, strengthened in this instance by the three brief sentences in which it is used.

- Parison is used in 1:27-28 to emphasise contrasting key concepts in Paul's explanation.

- Also emphatic is the placement of $\dot{\epsilon} \xi$ aنंtov at the beginning of 1:30, focussing on the activity of God.

- The change from $\dot{v} \mu \in \hat{\imath} S$ to $\dot{\eta} \mu \hat{\imath} \nu$ in a single sentence, as in $1: 30$, is a most effective way of creating intimacy between Paul and his audience.

To summarise: The rhetorical strategy in 1:26-31 could be described as "Using the contrast between divine and human wisdom to explain the calling of the Corinthians." In 1:26 Paul commands his audience to contemplate their past, thereby using an argument based on own experience to good effect. The explanation that follows is dominated by an argument based on divine initiative, while a shift in expectancy at the end of 1:28 stresses the complete vindication of God's wisdom over everything "that is."

An argument based on divine initiative is also used in 1:30 to emphasise

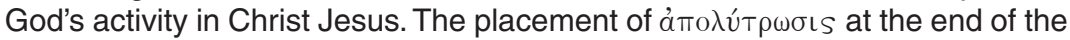
list emphasises redemption as the distinctive feature of God's wisdom, while an argument based on the authority of Scripture is finally used to convince the Corinthians to boast in the Lord, not in their own achievements. 
Rhetorical techniques supporting Paul's communication include epanaphora, parison, the placement of words and a change from second to first person plural in a single sentence.

\section{CONCLUSION}

The finding of this article is that Tolmie's proposal for a text-centered rhetorical analysis of Paul's letters provides a meaningful alternative to other existing approaches. Instead of forcing an external model upon a text or regarding only a few stylistic devices as rhetoric, an attempt was made to identify all the means of persuasion in 1 Corinthians 1:18-31 and to describe their function in context.

1 Corinthians 1:18-31 was demarcated on the basis of rhetorical considerations and divided into two sections: 1:18-25 and 1:26-31. In analysing these, the focus was on the way in which Paul argues, on the types of argument he uses and on the rhetorical techniques that enhance his communication. His argumentation in both sections is characterised by contrast, while examples of arguments based on divine initiative, on the authority of Scripture and on the Corinthians' own experience have also been found. Supportive rhetorical techniques such as repetition, brief sentences, the placement of words, parison, oxymoron, hyperbaton, the change of person in a single sentence, chiasm and epanaphora contribute to the impact of his communication and serve to persuade his audience to accept his explanation of the gospel. 


\section{BIBLIOGRAPY}

BARRETT, C.K.

1979. A commentary on the First Epistle to the Corinthians. London: Black. $2^{\text {nd }}$ ed.

BETZ, H.D.

1979. Galatians. A commentary of Paul's Letter to the churches in Galatia. Hermeneia. Philadelphia: Fortress.

BÜNKER, M.

1984. Briefformular und rhetorische Disposition im 1 Korintherbrief. GTA 28. Göttingen: Vandenhoeck \& Ruprecht.

Conzelmann, $\mathrm{H}$.

1975. 1 Corinthians: A commentary on the First Epistle to the Corinthians (Trans.). Hermeneia. Philadelphia: Fortress.

FEE, G.D.

1988. The First Epistle to the Corinthians. Grand Rapids: Eerdmans. (Reprint.)

Groenewald, E.P.

1967. Die Eerste Brief aan die Korinthiërs. Kaapstad-Pretoria: NGKU.

GrosheIDE, F.W.

1957. De Eerste Brief aan de Kerk te Korinthe. Kampen: N.V. Uitgeversmaatschappij J.H. Kok.

KISTEMAKER, S.I.

1993. New Testament Commentary. Exposition of the First Epistle to the Corinthians. Grand Rapids: Baker Books.

MarshaLl, P.

1987. Enmity in Corinth. WUNT 2/23. Tübingen: Mohr-Siebeck.

MitCheLL, M.

1991. Paul and the rhetoric of reconciliation: An exegetical investigation of the language and composition of 1 Corinthians. HUT 28. Tübingen: Mohr-Siebeck.

NidA, E.A., Louw, J.P., Snyman, A.H. \& Cronje, J.v.W.

1983. Style and discourse. Goodwood: N.B.P.

Pogoloff, S.M.

1992. Logos and Sophia: The rhetorical situation of 1 Corinthians. Atlanta: Scholars.

Schrage, W.

1991. Der erste Brief an die Korinther. 1 Teilband. EKKNT 7/1. Zürich: Benziger.

SCHÜSSLER-FIORENZA, E.

1987. Rhetorical situation and historical reconstruction in 1 Corinthians. NTS 33: 386-403. 
Snyman

1 Corinthians 1:18-31 from a rhetorical perspective

THISELTON, A.C.

2000. The First Epistle to the Corinthians. A commentary on the Greek text. NIGTC. Grand Rapids, Michigan, Cambridge: W.B. Eerdmans.

TOLMIE, D.F.

2005. Persuading the Galatians. A text-centred rhetorical analysis of a Pauline letter. WUNT 2/90. Tübingen: Mohr-Siebeck.

WITHERINGTON, B.

1995. Conflict and community in Corinth: A Socio-Rhetorical commentary on 1 and 2 Corinthians. Grand Rapids: Eerdmans.

Keywords

Pauline literature 1 Korintiërs 1:18-31 Rhetorical analysis
Trefwoorde

Pauliniese literatuur

1 Corinthians 1:18-31

Retoriese analise 